\title{
Nietzsche, Deleuze, and Nāgārjuna: Mapping the Dialectics of Will/Desire
}

\author{
Che-ming Yang \\ Department of Foreign Languages and Literature, National Cheng Kung University, Tainan, Taiwan \\ Email: yang5692@mail.ncku.edu.tw
}

\begin{abstract}
This paper aims to explore the correspondences between the dialectical analysis (the unique way of logical argumentation) of Nietzsche's will and that of Deleuze's desire - the discursive axis of two influential thinkers whose critiques of representation dominate the formation of postmodern theory and beyond. In addition, I make a comparative study of their dialectics and that of Nāgārjuna. The major Nietzschean/Deleuzean texts explored in this paper are some of those which foreground the everlasting deterritorialized movement of will (and its related themes-Overman and Eternal Recurrence) and desire: Nietzsche's Thus Spoke Zarathustra and The Will to Power; and Deleuze's Difference and Repetition, Nietzsche and Philosophy, Anti-Oedipus and A Thousand Plateaus. As for Nāgārjuna's work, I choose to focus on his masterpiece and mostly valued one-Mülamadhyamakakārikās (中論). The focus of this study is to attempt a mapping (characteristic of rhizomatics) of how their special dialectics of will/desire (Nihilism), without ever attempting to create another Absolute Truth, sets forth the non-totalizable multiplicities that characterizes the world of becoming
\end{abstract}

Index Terms - Nietzsche, Deleuze, Nāgārjuna, dialectics, will / desire

A book has neither object nor subject; it is made of variously formed matters, and very different dates and speeds... In a book, as in all things, there are lines of articulation or segmentarity, strata and territories; but also lines of flight, movements of deterritorialization and destratification... All this, lines and measurable speeds, constitutes an assemblage. A book is an assemblage of this kind, and as such is unattributable. It is a multiplicity... (A Thousand Plateaus 3-4)

All things in the world are devoid of an intrinsic nature, i.e. the things in the world are not as they appear to us. ${ }^{1}$

\section{INTRODUCTION}

Following Nietzsche's politics of will, in their collaborative works Anti-Oedipus and A Thousand Plateaus, Deleuze and Guattari, with their (micro)politics of desire, attempt to problematize and subvert Western metaphysical tradition that is marked by an obsessive desire for a Supreme Being/Truth (the arborescent model of thought that has been haunting the Western psyche since Plato). In other words, Deleuze and Guattari, in their politics of desire/difference (rhizomatics), hold a radical skepticism about the concept of the transcendental ego and certainties inherent in Western philosophical tradition, for they argue that the subject is missing in desire. Above all, in the second volume of their collaboration-A Thousand Plateaus, which is written in a more "schizo/rhizomatic" and self-reflexive text, Deleuze and Guattari endeavor to advocate a more thoroughly deconstructive analysis of the politics of desire. Consequently, challenging the concept of a unified subject and endeavoring to uproot philosophical trees, A Thousand Plateaus sets forth "a postmodern theory of non-totalizable multiplicity based on the concept of the 'rhizome,' their new term for deterritorialized movement" (Best \& Kellner, 1991, p.97).

Besides furthering the politics of difference and desire of Anti-Oedipus, Deleuze and Guattari also make some key changes in A Thousand Plateaus, especially they take pains to extend their application of theories of rhizomes to varied disciplines, ranging from linguistics, semiotics, to many other subjects such as noology and political economy. Moreover, its writing style is highly metafictional/self-reflexive (referential), for the authors argue that the book "imitates the world, as art imitates nature" (Deleuze and Guattari, 1992, p.5) and thus is itself a rhizome. As Best and Kellner rightly put it, A Thousand Plateaus "employs avant-garde writing techniques such that the 'form' of the book becomes part of its 'content' or rather, these distinctions break down" (Best \& Kellner, 1991, p.98). Likewise, in $A$ Thousand Plateaus (as the first epigraph of this paper reveals) the distinction between the subject and the object also breaks down in their philosophy of becoming/difference (Deleuze and Guattari, 1992, p.3). This writing strategy is characteristic of the postmodern -implosion, namely the collapse of boundaries - as Baudrillard defines it (the whole world in a broader sense is implosive).

However, most of the existent scholarship on Anti-Oedipus or A Thousand Plateaus (the research on it is comparatively insufficient when compared to that on Anti-Oedipus) just focuses on the study of their politics of desire/difference, without further exploring their dialectics (unique logical argumentations) in negating the partial view of reality inherent in traditional metaphysics. Viewed dialectically, Deleuze and Guattari's argumentation in the two 
volumes is presented through constant negating and deconstructing the arborescent discourses so as to foreground the invalidity/impossibility of discovering an ultimate truth. In other words, many scholars fail to examine Deleuze and Guattari's special dialectical argumentation that is aimed at negating all reductive "philosophical trees," a dialectical strategy to uncover the invalidity of all reductive thought by challenging it with some other ambiguous discourses that have multiple/contingent meanings, for reality is always becoming and multiple. Most importantly, Deleuze and Guattari do not in their dialectics create another Universal Absolute to replace the arborescent thought. To be more specific, though recognizing both everyday existence and the categories by which humans comprehend it are self-contradictory and incoherent, paradoxically, Deleuze and Guattari adopt a dialectical analysis to challenge and highlight the absurdities of metaphysics and morality and all other Western modes of thinking.

Likewise, though Nāgārjuna (龍樹菩薩, an Indian philosopher and saint who founded the Buddhist school Mādhyamika 中道, which holds a middle view of existence as voidness - no such thing as an intrinsic nature of all things) often refutes the validity of logic, most Buddhist scholars still consider his theoretical analysis as "dialectical" in a sense of "unique logical argumentation," for it constantly negates the use of logic in order to make plausible claim to improve on all previous metaphysical systems that it aims to refute.

Based on the Mādhyamika (中道) philosophy of emptiness/voidness (an empty logic), this paper intends to explore how A Thousand Plateaus sets forth a postmodern theory of non-totalizable multiplicity by furthering Nietzschean philosophy of becoming. In so doing, A Thousand Plateaus problematizes (representational) realities, deconstructs the transcendent subject/ego, and advocates a middle view of reality, physical or psychical, as voidness (the contingency and multiplicity of reality). In addition, this paper aims to examine the dialectics/middle view inherent in Deleuze and Guattari's rhizomatics - the unique way of logical argumentation through juxtaposing opposed/opposing terms or propositions and finally refuting both of them, without resorting to the Hegelian dialectics that is aimed at locating an ultimate Truth. Meanwhile, the correspondences between Nāgārjuna's dialectical method and that of Nietzsche/Deleuze (and Guattari) will be explored.

\section{VOIDNESS/IMPERMANENCE IN THE POSTMODERN IMPULSE OF RHIZOMATICS-THE PROBLEMS OF} (REPRESENTATIONAL) REALITY

In A Thousand Plateaus, Deleuze and Guattari seem to be intentionally parodying the modernist obsessive and ongoing pursuit for "autonomy and purity or for timeless, representational truth" (Bertens, 2002, p.5) in earthly multiplicities, for they claim that Nature is itself a rhizome, where "roots are taproots with a more multiple, lateral, and circular system of ramification, rather than a dichotomous one. Thought lags behind nature" (Deleuze and Guattari, 1992, p.5). Detecting this postmodern impulse in rhizomatics, Best and Kellner reveal that A Thousand Plateaus is "mainly concerned with a positive application of postmodern thinking that analyzes the rhizomatic nature of natural, social, and personal reality" (Best \& Kellner, 1991, p.98). Above all, Deleuze and Guattari set out to deconstruct in their second volume of collaboration "any binary oppositions left standing at the end of the first," namely, their "schizoanalytic 'deconstruction' (if it can be called that) derives from the unconscious logic of non-global connection and inclusive disjunction, as specified in the Anti-Oedipus." (Holland 1). Their logic, as Deleuze and Guattari declare, is a logic of an open-ended series "the AND"- "and... and ... and"-whose conjunction "carries enough force to shake and uproot the verb "to be"” (Deleuze and Guattari, 1992, p.25 ).

On the other hand, according to Nāgārjuna, a momentary entity or impermanent dharma (way or reality) is a contradictory concept. He points out that "what is impermanent and momentary can be divided into non-enduring or non-abiding moments and has, analytically, no duration whatever,"2 for it disappears as soon as it appears. Hence, we cannot say it has "true existence" (Cheng, 1991, p.77).

Consequently, attacking traditional ontology, Deleuze and Guattari not only echo this Buddhist view of voidness but also highlight the contingency and multiplicity of things in opposition to the metaphysical view of the existence of a permanent Ideal world beyond the transient and contingent everyday realities. That is, the central tenet of the Buddhist view of voidness corresponds to Deleuze and Guattari's empty logic_-all things in the world, physical or psychical, are subject to change, or to put it more specifically, there is no intrinsic nature in them.

In addition, Deleuze and Guattari also point out the uncertainty of realities by coining the concept of assemblage- "a multiplicity" (Deleuze and Guattari, 1992, p.4), by which they mean that all things in the world consist of lines and measurable speeds, but they also contain lines of flight/escape-"movements of deterritorialization and destratification"; the assembling and dissolution are subject to conditions or the law of relativity: "How could movements of deterritorialization and processes of reterritorialization not be relative (italics added), always connected, caught up in one another?" (Deleuze and Guattari, 1992, p.10). Moreover, they could connect or disconnect at any point with any lines (rhizomatic), as Deleuze and Guattari claim, the rhizome differs from a structure, because...the rhizome is made only of lines: lines of segmentarity and stratification as its dimensions, and the line of flight or deterritorialization as the maximum dimension after which the multiplicity undergoes metamorphosis changes in nature [italics added]. (Deleuze and Guattari, 1992, p.21)

\footnotetext{
${ }^{2}$ The Middle Treatise (Mūlamadhyamakakārikās 中論), XV: 1-2.
} 
The above-mentioned view of reality as impermanent actually not only echoes the Buddhist view of causality but also continues Nietzsche's politics of will (to power), for all of them are based on the theory of relativity. In Buddhist terminology, it is called “Dependent Origination" (十二因緣法 )—all things, inanimate or sentient, are interdependent/relativistic or conditioned, impermanent, and always in a flux of change. To be more specific, the law of causality is functioning according to our volitional activities/willing (ignorance).

On the other hand, this conception is also echoed in Deleuze's analysis of Nietzsche's ethics/ontology of power (will to power) as "a force which is related to another force: in this form force is call will. The will (will to power) is the differential element of force" (Deleuze, 1983, p.7). In terms of Deleuzean philosophy of desire/difference, the functioning of multiplicities is no more than a "network of plateaus" that are intersecting with one another and keep "deconstructing/multiplying a given set of terms until a point is reached at which they intersect with terms coming from deconstructions on other plateaus, without ever collapsing into or becoming identical with them. Such intersections will form a rhizome [emphasis added], something that develops 'au milieu': in the middle, in between" (Holland, 1999, p.2).

Viewed from the Buddhist perspective of the formation of things, material or mental, the rhizomatic conception assemblage is very similar to the Buddha's assertion that all things are comprised by the Five Aggregates (五藴). Further, this Buddhist cosmological law also refers to the impermanency of all worldly things. Since all worldly things are impermanent, subject to change; impermanence, declares the Buddha, is dukkha (苦). It is generally admitted that the term dukkha in the First Noble Truth, the first principle of the Four Noble Truths (四聖諦) 一 one of the central tenets of Buddhism that is also expounded by Nāgārjuna — bears an apparent meaning of ordinary suffering. But in addition, it also includes "imperfection," "impermanence," “emptiness," or "insubstantiality" (Rahula, 1959, p.17). The Buddha argues in the First Noble Truth (Dukka-ariyasacca) that in our world, all physical and spiritual phenomena are no more than the conditioned "combination of ever-changing physical and mental forces or energies, which may be divided into five groups or aggregates”-the Five Aggregates-Aggregates of Matter(色蘊), Sensation(受繿), Perceptions(想蘊), Mental Formations(行繿), and Consciousness(識蘊). The Buddha insists that any being or an individual or "I" is only a "convenient name or a label given to the combination of these five groups" (Samyutta-nikaya 421). The five aggregates are impermanent. The Buddha thus claims, in his very first sermon, that "Whatever is impermanent is dukkha... In brief the five Aggregates of Attachment are dukkha... They are in a flux of momentary arising and disappearing" (Dhammacakkappavattana-sutta, 1922, p. 9).

Moreover, in A Thousand Plateaus Deleuze and Guattari emphasize the collapse of the boundaries between the subject and the object, and that of beginning and end of any movement/action in nature. Nature is a rhizome full of contingent multiplicities that are not the representational copies of the immobile, unitary Platonic Ideal: It is not a multiplicity derived from the One, or to which One is added $(n+1) \ldots$ It has neither beginning nor end, but always a middle (milieu) from which it grows and which it overspills. It constitutes linear multiplicities with $n$ dimensions having neither subject nor object... When a multiplicity of this kind changes dimensions, it necessarily changes in nature as well, undergoes a metamorphosis. (Deleuze and Guattari, 1992, p.12)

This kind of deconstructive view of existence/reality happens to correspond to the Mādhyamika Middle View of reality_neither affirms nor denies the world, for "all things in the world are not as they appear to us," as the epigraph of this paper reveals.

\section{The MidDle VIEW In DELEUZE AND GUATTARI's DiAlectics}

In Nietzsche and Philosophy (1962), one of Deleuze's masterpieces which highlights that the reading of Nietzsche is central to his own philosophical project, Deleuze echoes and highly values Nietzsche's philosophy of becoming whose salient features are "flux, movement and creation" (Marks, 1998, p.25). Following Nietzsche's revolutionary and experimental nomadic/rhizomatic genealogy of Western reality and all Western thought, Deleuze furthers Nietzsche's philosophy of becoming/difference by coining many metaphors in A Thousand Plateaus (e.g. rhizome) to re-examine varied human disciplines. Deleuze's indebtedness to Nietzsche's nihilistic view of existence is also highlighted in $A$ Thousand Plateaus:

Nietzsche's aphorisms shatter the linear unity of knowledge, only to invoke the cyclic unity of the eternal return, present as the nonknown in thought... unity is consistently thwarted and obstructed in the object, while a new type of unity triumphs in the subject. The world has lost its pivot; the subject can no longer even dichotomize, but accedes to a higher unity, of ambivalence or overdetermination, in an always supplementary dimension to that of its object. The world has become chaos ... (Deleuze and Guattari, 1992, p.6)

Underlying the theories of becoming of Nietzsche and Deleuze is a deconstructive and dialectical impulse that is intended to uproot/negate philosophical trees whose partial views conceal the dynamic nature of reality-the micropolitics of will/desire.

What is worth our attention is that, though both Nietzsche and Deleuze vehemently attack the partial view of reality inherent in dialectics, paradoxically they also create a dialectics in refuting it. This is very characteristic of the postmodern parodic theorization. Furthermore, as Richardson indicates, Nietzsche's metaphysics is in many respects "a novel and sophisticated one that can make plausible claim to improve on all previous such systems" (Richardson, 1996). Following Nietzsche's metaphysics of becoming, Deleuze extends it to varied disciplines and thus creates a 
neo-Nietzschean dialectics that tries to deny the arborescent modes of thinking in every discipline. To achieve his goal, he devises the politics of desire that is actually a re-reading of Nietzsche's will. That kind of strategy is most manifest in A Thousand Plateaus.

To be more specific, like Nietzsche, Deleuze creates his own dialectics - a philosophy of contradictions in which "opposing ideas are presented in agonistic competition with one another" (Martin, 1991, p.24). Their dialectics happens to create a dynamic form of philosophizing that serves to deconstruct both sides of every equation and to illuminate the arbitrary and mutable character of the concepts themselves. Therefore, any extreme in a discourse in A Thousand Plateaus is always presented as contingent and au milieu (in the middle); the only unity or truth we can discover in any kind of sentence, text, or knowledge is no more than a "cyclic unity" that is also a multiplicity, for it "has neither subject nor object, only determinations, magnitudes, and dimensions that cannot increase in number without the multiplicity changing in nature" (Deleuze and Guattari, 1992, p.6-8).

For instance, Deleuze and Guattari keep stressing that they are not presenting opposed conceptions or realities even when they are elaborating on one pair of the most distinctively juxtaposed concepts in the book - root-tree/canal-rhizome, because this kind of discourse would finally lead to an ontological dualism:

The important point is that the root-tree and canal-rhizome are not two opposed models: the first operates as a transcendent model and tracing, even if it engenders its own escapes; the second operates as an immanent process that overturns the model and outlines a map... It is not a question of this or that place on earth, or of a given moment in history, still less of this or that category of thought. It is a question of a model that is perpetually in construction or collapsing, and a process that is perpetually prolonging itself, breaking off and starting up again. No, this is not a new or different dualism. (Deleuze and Guattari, 1992, p.20)

In other words, their dialectical method is no more than using a "convenient name or label" (according to the Buddhist conception of impermanence) to juxtapose some conflicting ideas and render them "agonistic" in the hope of proving that any extreme or fixed perspective we adhere to would ultimately fall into an ontological dualism, whenever we have to use some language to illuminate some idea, because that concept is always absent in the very language (and any other language as well) that we employ:

The problem of writing: in order to designate something exactly, anexact expressions (emphasis added) are utterly unavoidable. Not at all because it is a necessary step, or because one can only advance by approximations: anexactitude [italics added] is in no way an approximation; on the contrary, it is the exact passage of that which is under way. We invoke one dualism only in order to challenge another (emphasis added). (Deleuze and Guattari, 1992, p.20)

In fact, this is a philosophy of "contradictions" that Nāgārjuna also employs. Nāgārjuna's method of dialectics is called prasangāpādana, by which he refutes some concepts, categories, entities and characters, some principles and postulates of knowledge through showing the inner contradictions of his opponent's thought and furthermore, endeavoring "to use against him his own logic" (Bhattacharya, 1982, p. 89).

Above all, Nāgārjuna does not create or canonize another new idea as the rightful one. His methodology is to show the voidness in all worldly things, for they are devoid of an intrinsic nature (無自性故曰空). Hence, both Nāgārjuna's dialectical method and that of A Thousand Plateaus share many affinities, especially in their foregrounding the absence of validity/intrinsic nature in the "agonistically competing" ideas they juxtapose, although the more legitimate one in the opposed models is only an approximation.

In addition, Nāgārjuna concentrates his dialectics on the universals and postulates of the classical Nyāya System (an ancient Indian philosophical school) and on the elements, cluster of elements, pluralistic doctrines and dogmas of the Hinayana Buddhism. But some logicians challenge the Buddhist view of voidness on its logical argumentation as a double negation (i.e. the negation of a non-existent being - an intrinsic nature of all things) that happens to just affirm the thing that it tries to deny (A is not non-A). To render the logic of those logicians contradictory, Nāgārjuna uses against them their own logic by replying that this is a common misunderstanding of the meaning of voidness. The negation of the intrinsic nature, he argues, is not a denial of a real thing. Rather, it is a negation of a non-existent thing - the intrinsic nature of all things. That is, Nāgārjuna does not negate anything, for there is nothing to be negated-how can you negate something (the intrinsic nature of things) that never exists? Therefore, the function of the statement "All things are devoid of an intrinsic nature," says he, is to "make known the absence [my italics] of an intrinsic nature in things" (Kārikā and vŗtti LXIV). Consequently, as the Deleuzean nihilism is ambiguous and it echoes the Buddhist "Middle Path" (neither denies nor affirms the world), Deleuze's nihilism happens to coincide with Buddhist view of existence as voidness/impermanence.

More importantly, in the dialectics of Nāgārjuna and that of Deleuze and Guattari, we can detect the paradoxical nature of the (post)-postmodern vision of realities as foregrounded irresolvable contradictions (Hutcheon, 1988, p.47) ${ }^{3}$ and pluralities (multiplicities) eternally conflicting or assembling with each other on the plane of consistency. In other words, like Nietzsche, Deleuze and Guattari, though violently attacking the dialectical logic of locating an immobile Truth that transcends phenomenal contingencies, create a non-totalizing dialectics to deconstruct the arborescent/hierarchical organisms that stratify and subjectify flows/plateaus of desire.

\footnotetext{
${ }^{3}$ Linda Hutcheon (1988) in A Poetics of Postmodernism argues that "these contradictions of postmodernism are not really meant to be resolved, but rather are to be held in an ironic tension" (47).
} 
In addition, in their dialectical manner of analyzing the nature of existence in A Thousand Plateaus, Deleuze and Guattari create a metaphysics (theories of nihilism) that is aimed at "creating a movement which mirrors the very texture of existence: perpetual becoming, without metaphysical essence; a becoming [...] eternally without aim, meaning, or goal" (Martin, 1991, p.). Their metaphysical view of reality also argues the null positions in both epistemology (skepticism: no truth) and ontology (nihilism: no being).

Above all, both Deleuze/Nietzsche and Buddhism emphasize "the centrality of humans in a godless cosmos and neither looks to any external being or power for their respective solutions to the problems of existence" (Loy, 1998, p.129). ${ }^{4}$ In fact, their conceptions of "universal law," if any, are very similar, for all the three thinkers stress man's redemption from nihilism through his willing in the world of becoming. Nevertheless, Nāgārjuna argues from the Buddhist point of view that man should ultimately cease willing in order to consummate nirvana (涅槃), the state of non-self or the cease of willing/desiring (volitional activities), because desiring/willing is the cause/origin of either good or bad karma that generates the endless wheel of reincarnation. Besides, the discrepancy in their views regarding man's redemption from the impermanent world is too big a topic for me to explore in this short paper. What is most significant about their affinities in their philosophy of becoming is the middle view of reality that is focused on exposing the impermanency and multiplicity of all worldly knowledge and realities.

\section{CONCLUSION}

Despite some details of differences in their views of man's "ultimate" salvation, Deleuze (and Guattari) and Nāgārjuna share many affinities in their dialectical methods of refuting the absurdity of people's obsessive pursuit for an ultimate/immobile Truth. To sum up, the dominant theme of $A$ Thousand Plateaus is an attempt to undermine the principle of unitary identity, for it expounds the Nietzschean philosophy of affirmative becoming, which differs from the passive nihilism that lies in the heart of traditional metaphysics of subjectivity. The focus of this paper is only an attempt at mapping (characteristic of rhizomatics) how Deleuze and Guattari's special dialectics of desire (Nihilism), without ever attempting to create another Universal Absolute, sets forth the non-totalizable multiplicities that characterize the world of becoming. Their philosophy of becoming (rhizomatics) happens to echo the Mādhyamika (中道) philosophy of emptiness/voidness - an empty logic, founded by Nāgārjuna by illuminating the fundamental teaching of the Buddha on a middle view of existence/reality that can prevent us from being deluded by the appearances of worldly things.

\section{REFERENCES}

[1] Best, Steven, and Douglas Kellner. Postmodern theory. (1991). London: Macmillan.

[2] Cheng, Hsueh-li. (1991). Empty logic: Mādhyamika Buddhism from Chinese sources. Delhi: Motilal Banarsidass.

[3] Deleuze, Gilles. (1983). Nietzsche and philosophy. New York: Columbia UP.

[4] Deleuze, Gilles, and Fèlix Guattari. (1984). Anti-Oedipus: Capitalism and schizophrenia. London: Athlone.

[5] Deleuze, Gilles, and Fèlix Guattari. (1992). A thousand plateaus: Capitalism and schizophrenia. London: Athlone.

[6] Dhammacakkappavattana-sutta. (1922). Setting in Motion the Wheel of Truth. Alutgama: Mhvg.

[7] Holland, Eugene W. (1999). Deleuze and Guattari's Anti-Oedipus: Introduction to schizoanaylsis. London: Routledge.

[8] Hutcheon, Linda. (1988). A poetics of postmodernism: History, theory, fiction. New York: Routledge.

[9] Lowenstein, Tom. (1996). The vision of the Buddha. London: Duncan Baird.

[10] Loy, David R. (1984). Rev. of Nietzsche and Buddhism: A study in nihilism and ironic affinities, by Robert Morrison. Asian Philosophy 8.2: 129-31.

[11] Marks, John. (1998). Gilles Deleuze: Vitalism and multiplicity. London: Pluto.

[12] Martin, Glen T. (1991). Deconstruction and breakthrough in Nietzsche and Nagarjuna. Nietzsche and Asian thought. Ed. Graham Parkes. Chicago: U of Chicago P, 91-242.

[13] Morrison, Robert. (1997). Nietzsche and Buddhism: A Study in Nihilism and Ironic Affinities. Oxford: Oxford UP.

[14] Nagarjuna. (1960). Mūlamadhyamakakārikās, with commentary: Prasannapadā by Candrakirti. Edited by P. L. Vaidya. Darbhanga: Mithila Institute (Buddhist Sanskrit Texts No. 10).

[15] Nagarjuna. (1982). Vigrahavyavartani. Trans. Kamaleswar Bhattacharya. Colombo: Motilal Banarsidass.

[16] Nietzsche, Friedrich. (1968). The will to power. Trans. Walter Kaufmann and R. J. Hollingdale. Ed. Walter Kaufmann. New York: Vintage.

[17] Rahula, Walpola Sri. (1959). What the Buddha taught. London: Gordon Fraser.

[18] Rajapakse, Vijitha. (1984). Rev. of "Nietzsche and Buddhism: Prolegomenon to a Comparative Study," by Freny Mistry. Philosophy East \& West 34, 332-35.

[19] Richardson, John. (1996). Nietzsche's system. Oxford: Oxford UP.

Che-ming Yang was conferred with a PhD. in English and American Literature in 1999 by the Department of English, National Taiwan Normal University, Taipei, Taiwan.

\footnotetext{
${ }^{4}$ See David R. Loy's review on Morrison's Nietzsche and Buddhism: A Study in Nihilism and Ironic Affinities, Asian Philosophy Vol. 8.2 (July 1998): 129-31. In my opinion, following Nietzsche's philosophy of becoming (nihilism) that denies the omnipotence of God, Deleuze's politics of desire also shares this affinity with Buddhism that stresses man's desiring constitutes his contingent being.
} 
$\mathrm{He}$ is currently teaching as an associate professor at the Department of Foreign Languages and Literature, National Cheng Kung University, Tainan, Taiwan. Besides his doctoral thesis, which is devoted to the study of a poetics of postmodernism, Dr. Yang has published a book on Deleuzian literary aesthetics (Taipei: Bookman, 2003). His major research interests are postmodernism and postmodernist fiction, Cultural Studies with a focus on the issues of identity and representation on the mass media, comparative studies between western philosophy and Buddhism, Deleuze studies.

Besides several national research grants from the Taiwanese National Science Council (NSC), Dr. Yang was granted a research grant by the Fulbright Foundation (U.S.A.) in 2003 and thus was able to undertake a short-term study of contemporary American literature at Northern Illinois University, U.S.A., in the summer of the same year. Dr. Yang is now a member on the Editorial Board of Arts and Social Science Journal, AstonJournals, located in Portland, U.S.A. 